\title{
Regulation of Erythropoiesis. XV. Neonatal Erythropoiesis and the Effect of Nephrectomy *
}

\author{
Guido Lucarelli, $†$ Donald Howard, and Frederick Stohlman, Jr.
}

(From St. Elizabeth's Hospital, Tufts Medical School, Boston, Mass.)

The importance of erythropoietin as a regulator of erythropoiesis is undeniable, but that it is the sole regulator is controversial. Fried, Plzak, Jacobson, and Goldwasser (1) proposed a simple, unified concept for the regulation of red cell production. They suggested that the relationship of oxygen supply to demand governs the production of erythropoietin, which, in turn, through differentiation of the stem cells controls red cell production. An increased cell mass, e.g., through transfusion, in the presence of a normal $\mathrm{Po}_{2}$ would decrease erythropoietin production and erythropoiesis by increasing the oxygen supply. Conversely, anemia by decreasing the $\mathrm{O}_{2}$ supply would stimulate erythropoietin production. Changes in metabolic rate, e.g., starvation, would affect erythropoietin production and, hence, erythropoiesis by changes in $\mathrm{O}_{2}$ demand. As attractive as this hypothesis is, it does not appear to offer a satisfactory explanation for compensated hemolytic states (2), continued production of substantial numbers of red cells, although fewer than normal, in the polycythemic dog (3), or the stimulating effect of hemoglobin recently reported by Brown, Altschuler, and Cooper (4) and Sánchez-Medal, Labardini, and Loría (5).

Jacobson, Goldwasser, Fried, and Plzak proposed the kidney as the site of production of erythropoietin (6). This conclusion was based on the striking decrease in erythropoiesis observed after bilateral nephrectomy but not ureteral ligation in the rodent. Similiar findings were reported by Naets in the $\operatorname{dog}(7)$, but Nathan, Schupak, Stohlman, and Merrill (8) observed substantially less suppression of red cell production in anephric

\footnotetext{
* Submitted for publication May 18, 1964; accepted July 20, 1964.

Supported by grants HE-07542 and HTS-5600 from the National Heart Institute.

$\dagger$ Foreign Postdoctoral Fellow (FF-658) of the U. S. Public Health Service.
}

man. The general experience is that erythropoietin cannot be demonstrated in the plasma of nephrectomized animals after the administration of cobalt, bleeding, or hypoxia (9), but the renoprival rodent and $d o g$ respond to erythropoietin. Mirand, Prentice, and Slaunwhite, however, reported substantial erythropoietin in the plasma of nephrectomized animals exposed to hypoxia (10). In these studies the hypophysectomized animal was used for assay; this type of assay animal may be influenced by substances other than erythropoietin. The most direct evidence for the renal origin of erythropoietin is the observations of Kuratowska, Lewartowski, and Michalak (11), Reissmann and Nomura (12), and Fisher, Sanzari, Birdwell, and Crook (13) of erythropoietin in renal vein blood after perfusion of the isolated kidney with cobalt or hypoxic blood. These studies appear to indicate that the kidney is a major if not the sole site for erythropoietin production. That there may be other sites (or regulators) stems from the observation of a significant but suboptimal erythropoietic response of the hypoxic nephrectomized rat where azotemia was averted by placing the nephrectomized rat in parabiosis with a normal partner at ambient pressure (14).

Polycythemia induced by hypertransfusion of the pregnant rat suppresses maternal but not fetal erythropoiesis (15). From this Jacobson, Marks, and Gaston concluded that fetal erythropoiesis operates independently of maternal erythropoiesis. The explanation could be either that the fetus produces erythropoietin, in which case it can be inferred that erythropoietin does not cross the placental barrier to the mother, or that fetal erythropoiesis operates independently of the erythropoietic mechanism. In favor of the latter explanation is that erythropoiesis develops before the functionally intact kidney. It is possible, nevertheless, as Jacobson suggested (15), that a primi- 


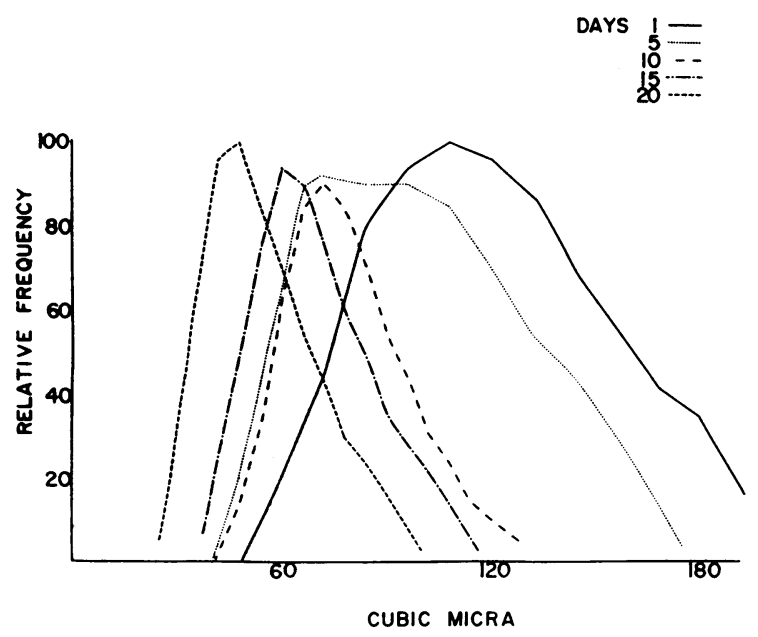

Fig. 1. Representative Red CELl Size distribution Curves. Days refer to the time after birth. The modal value on day 20 is similar to that of the normal adult, but there is more skewing to the right, leading to a slightly higher MCV.

tive renal anlage serves as the source of erythropoietin.

The newborn rat passes through a period of intense erythropoiesis in the face of a relatively mild anemia. This together with the possibility that fetal erythropoiesis, as discussed above, may not be governed by erythropoietin suggested the newborn rat as a possible subject for the study of alternative mechanisms for the control of erythropoiesis. The changes in red cell production during the neonatal period and the effect of nephrectomy thereon are the subject of this report.

\section{Methods}

Sprague-Dawley (NIH) rats were mated at 3 to 4 months of age. The fetuses were delivered spontaneously. Blood samples were collected from anesthetized animals into Versenate by decapitation until the fifteenth day of life and by cardiac puncture thereafter. Red cell values were measured by standard technics, reticulocytes were stained with new methylene blue, and cell size distribution was measured with a Coulter model B and Graphout (16). Imprint smears were obtained from the split femur, liver, and spleen through the fifteenth day; thereafter a brush technic was used. These preparations were stained with Wright's and Giemsa. One to five thousand cells were classified by the usual morphologic criteria, and the mitotic index was determined. A few pregnant mothers were sacrificed and differentials on the fetal liver estimated; at this time the bone marrow had not formed and splenic tissue was not obtained. In experiments in which the mother received transfusions, an amount of blood equivalent to $3 \%$ of the body weight was given on each of three occasions during the last 5 days of pregnancy. Nephrectomy was performed under light Nembutal anesthesia up to the fifteenth day of life and under light ether anesthesia in older animals. The newborn animals were washed with Bactine after the operation.

\section{Results}

Normal erythropoiesis in the neonatal period. Representative peripheral blood changes during the neonatal period are given in Table I. At birth the rats had a mild anemia characterized by hypochromia, striking macrocytosis, and reticulocytosis. During the first week of life, the hemoglobin decreased to a minimal value of $\sim 8 \mathrm{~g}$ per $100 \mathrm{ml}$. The reticulocyte values remained markedly elevated. In part the reticulocytosis may be explained by an increase in red cell production to compensate for the rapidly expanding blood volume of the growing animal. That this is not the entire explanation may be inferred from a consideration of the degree of reticulocytosis. During the first 5 days there was a doubling of body weight. If one assumes a doubling of blood vol-

TABLE I

Mean peripheral blood values for six animals $\pm 1 S E$ at various ages in the rat

\begin{tabular}{|c|c|c|c|c|c|c|c|}
\hline Age & & Teight & Hematocrit & Hemoglobin & $\mathrm{MCV}^{*}$ & $\mathrm{MCHC} *$ & Reticulocytes \\
\hline days & & $g$ & $\%$ & $\mathrm{~g} / 100 \mathrm{ml}$ & $\mu^{3}$ & $\%$ & $\%$ \\
\hline 1 & 6.7 & \pm 0.16 & $34 \pm 1.3$ & $10.2 \pm 0.4$ & $136 \pm 2.2$ & \pm 0.3 & \pm 0.7 \\
\hline 5 & 13.7 & \pm 0.48 & $29.3 \pm 0.7$ & $8.3 \pm 0.4$ & \pm 2.9 & $28.7 \pm 1.0$ & \pm 2.9 \\
\hline 10 & 21 & \pm 0.81 & $30.3 \pm 0.6$ & $8.6 \pm 0.4$ & \pm 1.8 & $27.7 \pm 0.8$ & $\pm 2 / 3$ \\
\hline 20 & 47 & \pm 2.7 & $32.5 \pm 1.3$ & $9.5 \pm 0.5$ & \pm 2.3 & $29.3 \pm 0.97$ & \pm 1.5 \\
\hline 30 & 84 & \pm 3.9 & $40 \pm 0.1$ & $12.2 \pm$ & $63 \pm 1.1$ & $31 \pm 0.1$ & $6.6 \pm 1.5$ \\
\hline 40 & 123 & \pm 10.1 & $42.4 \pm 0.6$ & $13.9 \pm 0.3$ & $61.5 \pm 1.3$ & \pm 0.4 & $3.7 \pm 0.44$ \\
\hline 67 & 153 & \pm 4.4 & $44.0 \pm 1.1$ & $14.4 \pm 0.3$ & $55.3 \pm 0.8$ & \pm 0.3 & $2.3 \pm 0.26$ \\
\hline
\end{tabular}

${ }^{*} \mathrm{MCV}=$ mean corpuscular volume $\mathrm{MCHC}=$ mean corpuscular hemoglobin concentration. 


\section{RED CELL PRECURSORS PER CENT NUCLEATED CELLS}

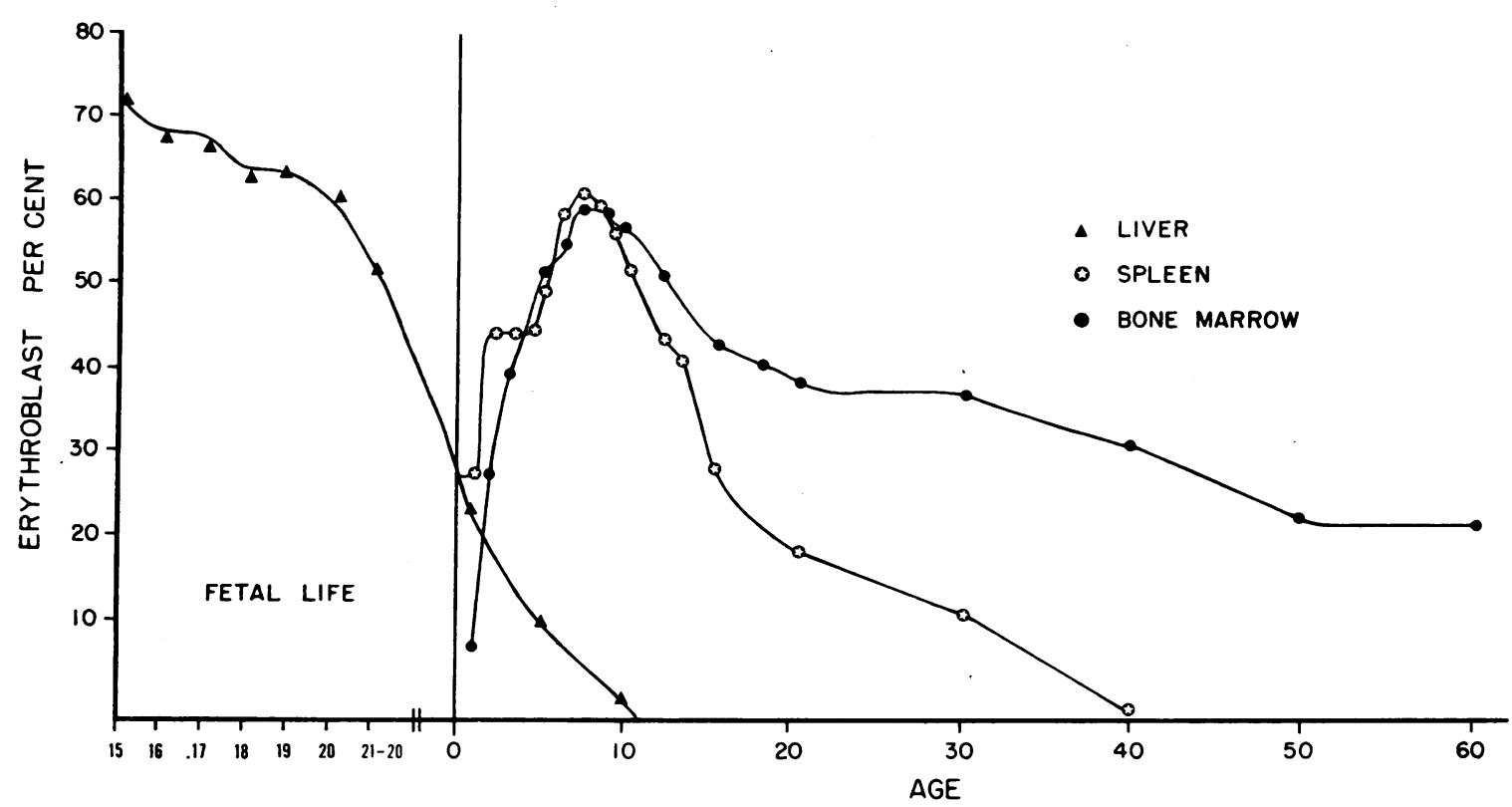

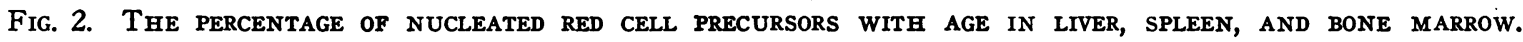
Fetal values are based on the mean of 8 animals per point; splenic and liver values in the newborn are the mean of 6 animals per point; and bone marrow values represent the mean of 8 to 14 animals for each point.

ume, the observed reticulocyte value of $45 \%$ on day 5 would require a maturation time for reticulocytes of the order of 4 to 5 days. This in view of previous estimates of reticulocyte maturation time seems unlikely, and hemolysis is implicated. Further evidence for red cell destruction was obtained from evaluation of red cell size distribution curves (Figure 1). On the first day of life a macrocytic population with a modal value of 108 $\mu^{3}$ and many cells in excess of $150 \mu^{3}$ was present. This gradually changed so that by day 20 the red cells had a normal modal value of $48 \mu^{3}$ although some macrocytes were still present, leading to a slightly elevated mean corpuscular volume (MCV) of $67 \mu^{3}$. Shrinkage of cells can be excluded, since the mean corpuscular hemoglobin concentration (MCHC) did not increase. Since the cell size distribution curves give the relative frequency of cells of a given size, it is to be expected that in part the observed changes in the distribution curve reflect dilution of the macrocytic population by newly formed, normal sized cells. That this is not the entire explanation but that there was a shortened life span of the early macrocytic population can be inferred from cor- relation of the proportion of day 1 cells expected to be circulating on a given day, if survival were normal, and an assumption in respect to the blood volume. On day 10 the birth weight had increased threefold; a maximum of a threefold increase in blood volume would be anticipated. If survival were normal, then $30 \%$ of the cells should have been those present on day 1. Analysis of distribution curves indicated that $\sim 75 \%$ of the cells on day 1 had a corpuscular volume of $108 \mu^{3}$ or greater. If these cells survived normally and dilution alone accounted for the shift in cell size distribution, then at least $\sim 22 \%$ of the cells present on day 10 should have had a cell volume of $108 \mu^{3}$ or greater. In fact, on day 10 the cells with volumes of $108 \mu^{3}$ or greater accounted for $\sim 11 \%$ of the total cell population. It may be inferred that significant destruction, of the order of $50 \%$, of the day 1 macrocytes occurred. Another unusual feature of the peripheral blood of newborn rats is the presence of substantial hypochromia during the first 3 weeks of life. Between the twentieth and fortieth days the hematocrit and hemoglobins rose, the reticulocytes declined, and the MCV and $\mathrm{MCHC}$ changed in 
TABLE II

Relative numbers of nucleated cells in the normal rat*

\begin{tabular}{|c|c|c|c|c|c|c|c|c|c|c|}
\hline $\begin{array}{c}\text { No. } \\
\text { of } \\
\text { animals }\end{array}$ & Age & Primitive & $\begin{array}{l}\text { Mono- } \\
\text { nuclear }\end{array}$ & Myeloid & Lymphoid & $\begin{array}{c}\text { Erythro- } \\
\text { blast }\end{array}$ & Prn & $\mathrm{BN}$ & $P N$ & $\underset{\text { (red) }}{\text { MI }}$ \\
\hline & days & $\%$ & $\%$ & $\%$ & $\%$ & $\%$ & $\%$ & $\%$ & $\%$ & $\%$ \\
\hline 9 & 1 & $\begin{array}{l}9 \\
1-26\end{array}$ & $\begin{array}{l}2 \\
2-4\end{array}$ & $\begin{array}{l}70 \\
46-86\end{array}$ & $\stackrel{12}{4-18}$ & $\begin{array}{l}6 \\
3-12\end{array}$ & $\begin{array}{l}2 \\
1-4\end{array}$ & $\begin{array}{l}3 \\
1-10\end{array}$ & ${ }_{2-11}^{1}$ & $\begin{array}{l}4 \\
1-12\end{array}$ \\
\hline 7 & 3 & $\stackrel{14}{7-26}$ & $\begin{array}{l}2 \\
2-5\end{array}$ & ${ }_{3-7}^{35}$ & $\begin{array}{l}5 \\
4-19\end{array}$ & $\begin{array}{l}43 \\
17-70\end{array}$ & $\begin{array}{l}7 \\
3-13\end{array}$ & $\stackrel{15}{6-29}$ & $\stackrel{22}{3-27}$ & $\begin{array}{l}5 \\
1-7\end{array}$ \\
\hline 6 & 5 & $\begin{array}{l}15 \\
12-18\end{array}$ & $\begin{array}{l}2 \\
1-4\end{array}$ & $\begin{array}{l}22 \\
14-41\end{array}$ & $\begin{array}{l}9 \\
5-15\end{array}$ & $\begin{array}{l}52 \\
35-61\end{array}$ & $\begin{array}{l}4 \\
3-7\end{array}$ & $\stackrel{14}{7-20}$ & $\begin{array}{l}34 \\
24-35\end{array}$ & $\begin{array}{l}5 \\
3-7\end{array}$ \\
\hline 8 & 8 & $\begin{array}{l}7 \\
5-12\end{array}$ & $\begin{array}{l}3 \\
1-6\end{array}$ & $\begin{array}{l}17 \\
12-20\end{array}$ & $\stackrel{14}{6-19}$ & $\begin{array}{l}59 \\
43-64\end{array}$ & $\begin{array}{l}9 \\
6-16\end{array}$ & $\begin{array}{l}21 \\
15-28\end{array}$ & $\begin{array}{l}29 \\
23-34\end{array}$ & $\begin{array}{l}5 \\
3-7\end{array}$ \\
\hline 7 & 10 & $\begin{array}{l}8 \\
5-14\end{array}$ & $\begin{array}{l}3 \\
2-6\end{array}$ & $\begin{array}{l}21 \\
13-25\end{array}$ & $\stackrel{14}{7-25}$ & $\begin{array}{l}54 \\
40-69\end{array}$ & ${ }_{6-14}^{10}$ & $\begin{array}{l}18 \\
12-24\end{array}$ & $\begin{array}{l}26 \\
14-35\end{array}$ & $\begin{array}{l}4 \\
2-5\end{array}$ \\
\hline 5 & 15 & $\begin{array}{l}5 \\
3-10\end{array}$ & $\begin{array}{l}4 \\
3-9\end{array}$ & $\begin{array}{l}26 \\
17-44\end{array}$ & $\begin{array}{l}23 \\
11-36\end{array}$ & $\begin{array}{l}42 \\
40-47\end{array}$ & $\begin{array}{l}8 \\
3-11\end{array}$ & $\begin{array}{l}14 \\
12-16\end{array}$ & $\begin{array}{l}20 \\
13-24\end{array}$ & $\begin{array}{l}4 \\
2-4\end{array}$ \\
\hline 6 & 20 & $\begin{array}{l}6 \\
4-9\end{array}$ & $\begin{array}{l}6 \\
2-11\end{array}$ & $\begin{array}{l}25 \\
15-47\end{array}$ & $\stackrel{23}{6-32}$ & $\begin{array}{l}40 \\
32-50\end{array}$ & $\begin{array}{l}8 \\
4-10\end{array}$ & $\stackrel{14}{9-19}$ & $\begin{array}{l}18 \\
14-23\end{array}$ & $\begin{array}{l}3 \\
2-4\end{array}$ \\
\hline 4 & 32 & $\begin{array}{l}2 \\
1-3\end{array}$ & $\begin{array}{l}2 \\
2-3\end{array}$ & $\begin{array}{l}42 \\
41-50\end{array}$ & $\begin{array}{l}15 \\
12-18\end{array}$ & $\begin{array}{l}39 \\
32-43\end{array}$ & $\begin{array}{l}5 \\
5-5\end{array}$ & ${ }_{10-12}^{12}$ & $\begin{array}{l}22 \\
14-24\end{array}$ & $\stackrel{2}{1-3}$ \\
\hline 8 & 43 & $\begin{array}{l}3 \\
1-4\end{array}$ & $\begin{array}{l}3 \\
1-6\end{array}$ & $\begin{array}{l}41 \\
23-51\end{array}$ & $\begin{array}{l}18 \\
10-25\end{array}$ & $\begin{array}{l}35 \\
28-43\end{array}$ & $\begin{array}{l}5 \\
3-7\end{array}$ & $\stackrel{10}{9-14}^{10}$ & $\begin{array}{l}20 \\
14-23\end{array}$ & $\begin{array}{l}3 \\
1-5\end{array}$ \\
\hline 4 & 60 & $\begin{array}{l}6 \\
4-8\end{array}$ & $\begin{array}{l}5 \\
3-6\end{array}$ & $\begin{array}{l}46 \\
45-50\end{array}$ & $\begin{array}{l}17 \\
12-24\end{array}$ & $\begin{array}{l}26 \\
20-32\end{array}$ & $\begin{array}{l}4 \\
2-4\end{array}$ & $\begin{array}{l}7 \\
5-8\end{array}$ & $\begin{array}{l}15 \\
12-16\end{array}$ & $\stackrel{2}{0-4}$ \\
\hline
\end{tabular}

* The age refers to the day of sacrifice. The average value for each class is given above with the range below. Primitive cells during the first 30 days of life are a syncytial type of cell described in text; thereafter, they are reticulum cells. Complete agreement on distinguishing hemocytoblasts (Ferrata) and lymphoblasts could not be achieved; accordingly, these are classified as mononuclear cells. The total percentage of nucleated red cells is given under erythroblasts; the cells are further subdivided into prn, pronormoblast; BN, basophilic normoblast; PN, polychromatophilic normoblasts and the rare orthochromatic normoblast. The values for the latter are as per cent of the total nucleated marrow population. The mitotic index (MI) refers only to the red cell elements.

the direction of normal. On day 40 the hemoglobin, hematocrit, and MCHC were normal; the reticulocyte count was slightly elevated, $3.7 \%$, as was the $\mathrm{MCV}, \sim 62$. By day 67 all peripheral red cell values were within the normal range for adults.

At birth the only differentiated cells in the bone marrow were myeloid. Considerable erythroid activity was present in the liver and in the spleen (Figure 2). Within the next 5 days there was an explosive increase in erythropoiesis in the bone marrow, a further increase in erythroid activity of the spleen, but declining red cell production in the liver. The very rapidity of the increase in erythropoiesis led to substantial variation in the estimate of per cent of erythroid cells in the first few days; a few hours' error in estimating the time of birth, when delivery occurred during the night, would result in a substantial difference in the proportion of red cell precursors. Bone marrow erythroid activity was at a maximum on the sixth to eighth days and thereafter declined until the adult differential was achieved between days 40 and 60 (Figure 2, Table II). Splenic erythropoiesis declined more rapidly, reaching adult val- ues by the fortieth day, and hepatic erythropoiesis was not seen after the tenth day.

The differential counts of the bone marrow are given in Table II. During the first 20 to 30 days there was a primitive cell present in the bone marrow that bore a striking similarity to a cell seen in the liver during the hepatic phase of erythropoiesis at a time when the only other morphologic entities present are erythroid cells. For this reason we consider this cell as probably the stem cell. It usually occurred in a syncytial network and had a nuclear diameter of 15 to $20 \mu$; the nucleus was leptochromatic, stained a light pink, and had a somewhat spongy appearance. The cytoplasm was faintly basophilic with fine vacuolization. Where cell membranes were distinct, the cell was 30 to $40 \mu$ in diameter. Usually, however, it appeared as a syncytium. After 30 days of life, occasional cells with a similar appearance were seen, but there was no syncytium. After this time, reticulum cells and cells that were difficult to distinguish between hemocytoblasts (Ferrata) and lymphoblasts were present in substantial numbers; the latter cells were grouped as mononuclear cells. Lymphocytes also were more frequent. Of in- 
RED CELL PRECURSORS PER CENT NUCLEATED CELLS IN BONE MARROW

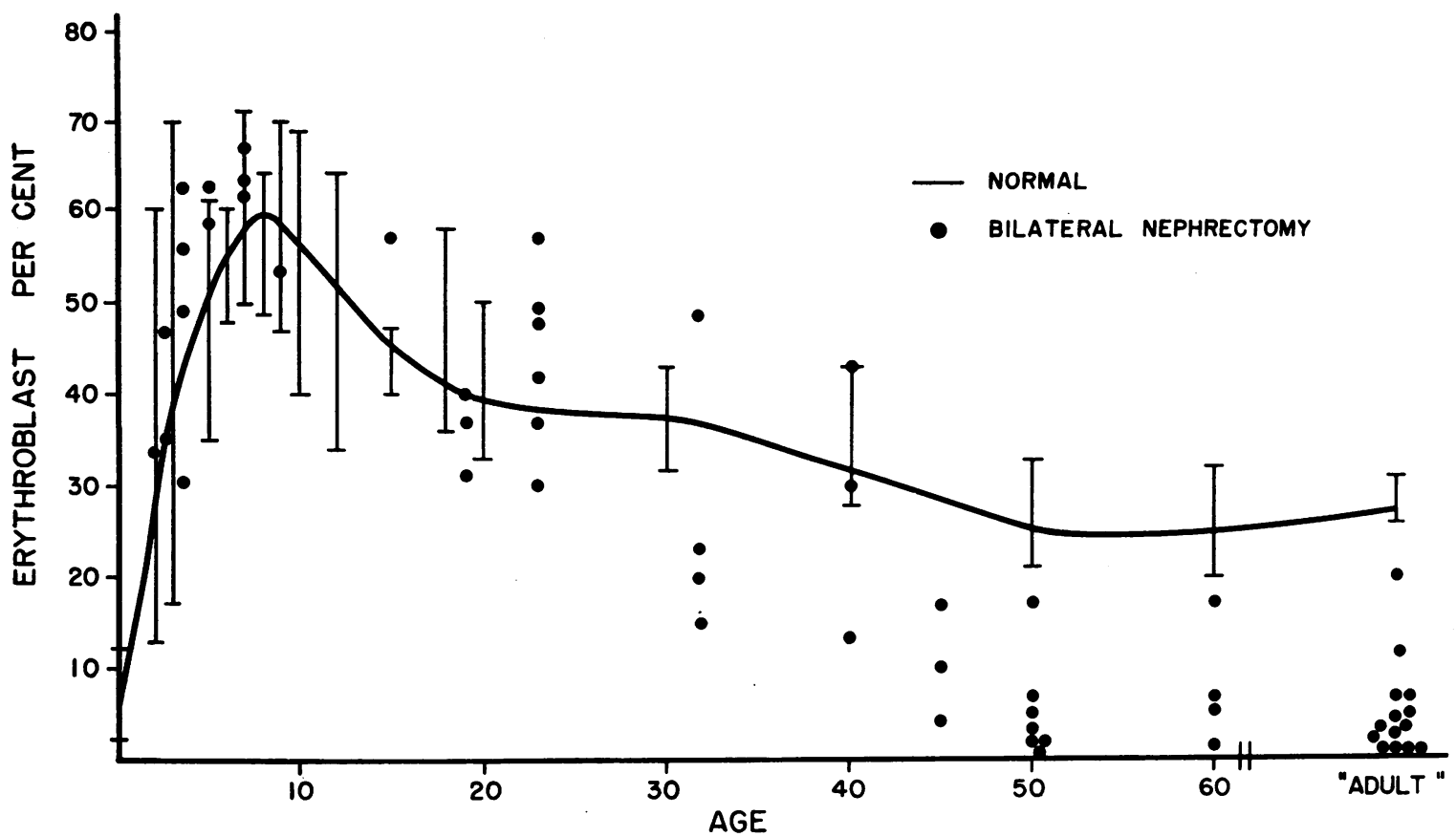

Fig. 3. The effect of NePhrectomy on the PERCENTAge of NuCleated Red Cells in the Bone MarRow. The line represents the normal average with the range indicated by the bars. Each point represents a nephrectomized animal.

terest was the high mitotic index in the erythroid series, 3 to $5 \%$ during the neonatal period as contrasted to the value of 1 to $2 \%$ seen in adult marrows (Table II).

Erythropoiesis in the nephrectomized rat. Rats were nephrectomized at various intervals during the neonatal and adult periods. The animals were sacrificed between 40 and 72 hours after nephrectomy. In the adult nephrectomized rat there was a gradual suppression of erythropoiesis so that by 48 hours the red cell precursors in the bone marrow were predominantly late forms with occasional basophilic normoblasts. Mitotic figures were rare. In most rats after 72 hours only late polychromatophilic erythroid cells were present, and these were usually few in number. In an occasional rat the percentage of erythroid cells, although decreased, is still substantial. In these instances the cells were predominantly late polychromatophilic normoblasts with only a rare basophilic normoblast; mitoses were not present.

In contrast, during the first 20 days of life nephrectomy did not importantly alter the bone marrow either in terms of the percentage of erythroid precursors (Figure 3 ) or the erythroid differential per se (Table III). The mitotic index also was unaffected. Between the twentieth and fortieth days of life the response to nephrectomy gradually changed over to that seen in adult life. Although there was individual variation, the trend was clear with a decreasing proportion of red cell precursors, early erythroid cells, and mitotic index (Table III). After day 40 the response to nephrectomy was similar to that seen in adults. Although the numbers were too small to permit other than a tentative statement, nephrectomy did appear to cause a decrease in the proportion of primitive cells after $\sim$ day 20 and a relative increase in myeloid and lymphoid elements.

Since Grant (17) reported that erythropoietin can be transmitted to the newborn through maternal milk, it seemed necessary to exclude this as a possible stimulus for erythropoiesis in the nephrectomized newborn. Accordingly, the effect of nephrectomy was evaluated in animals nursing from hypertransfused mothers compared with litter mate controls.

A representative study on the effect of induc- 
TABLE III

Relative number of nucleated cells in the bone marrow of nephrectomized rats*

\begin{tabular}{|c|c|c|c|c|c|c|c|c|c|c|}
\hline $\begin{array}{c}\text { No. } \\
\text { of } \\
\text { animals }\end{array}$ & Age & Primitive & $\begin{array}{l}\text { Mono- } \\
\text { nuclear }\end{array}$ & Myeloid & Lymphoid & $\begin{array}{c}\text { Erythro- } \\
\text { blast }\end{array}$ & Prn & $\mathrm{BN}$ & PN & $\underset{(\text { red) }}{\text { MI }}$ \\
\hline & days & $\%$ & $\%$ & $\%$ & $\%$ & $\%$ & $\%$ & $\%$ & $\%$ & $\%$ \\
\hline 3 & 3 & $\begin{array}{l}15 \\
13-20\end{array}$ & $\begin{array}{l}2 \\
1-3\end{array}$ & $\begin{array}{l}19 \\
10-31\end{array}$ & $\stackrel{12}{2-16}$ & $\begin{array}{l}52 \\
35-74\end{array}$ & ${ }_{7-15}^{10}$ & $\stackrel{20}{9-33}$ & $\begin{array}{l}22 \\
16-32\end{array}$ & $\begin{array}{l}4 \\
2-6\end{array}$ \\
\hline 4 & $3 \frac{1}{2}$ & $\begin{array}{l}20 \\
15-30\end{array}$ & $\begin{array}{l}2 \\
1-4\end{array}$ & ${ }_{6}^{16}-30$ & $\stackrel{12}{3-17}$ & $\begin{array}{l}50 \\
30-63\end{array}$ & $\begin{array}{l}7 \\
5-13\end{array}$ & $\stackrel{15}{8-30}$ & $\begin{array}{l}28 \\
18-43\end{array}$ & $\begin{array}{l}5 \\
3-9\end{array}$ \\
\hline 3 & 7 & $\begin{array}{l}8 \\
8-9\end{array}$ & $\begin{array}{l}3 \\
2-4\end{array}$ & $\begin{array}{l}14 \\
14-14\end{array}$ & $\begin{array}{l}12 \\
8-14\end{array}$ & $\begin{array}{l}64 \\
62-67\end{array}$ & $\begin{array}{l}9 \\
4-14\end{array}$ & $\begin{array}{l}23 \\
20-27\end{array}$ & $\begin{array}{l}32 \\
21-39\end{array}$ & $\begin{array}{l}4 \\
2-5\end{array}$ \\
\hline 1 & 15 & 4 & 5 & 19 & 14 & 58 & 10 & 22 & 26 & 3 \\
\hline 3 & 19 & $\begin{array}{l}3 \\
3-4\end{array}$ & $\begin{array}{l}2 \\
1-3\end{array}$ & $\begin{array}{l}51 \\
48-59\end{array}$ & $\begin{array}{l}8 \\
6-11\end{array}$ & $\begin{array}{l}36 \\
31-40\end{array}$ & $\begin{array}{l}6 \\
3-9\end{array}$ & ${ }_{7-1.3}^{11}$ & $\begin{array}{l}19 \\
15-21\end{array}$ & $\begin{array}{l}3 \\
2-5\end{array}$ \\
\hline 6 & 23 & $\begin{array}{l}3 \\
2-5\end{array}$ & $\begin{array}{l}2 \\
1-4\end{array}$ & $\begin{array}{l}32 \\
25-48\end{array}$ & $\begin{array}{l}19 \\
12-27\end{array}$ & $\begin{array}{l}44 \\
30-57\end{array}$ & $\begin{array}{l}4 \\
2-6\end{array}$ & $\begin{array}{l}13 \\
10-17\end{array}$ & $\begin{array}{l}27 \\
16-41\end{array}$ & $\begin{array}{l}1 \\
0-2\end{array}$ \\
\hline \multirow[t]{2}{*}{4} & 32 & $\begin{array}{l}2 \\
1-4\end{array}$ & $\stackrel{1}{0.5-2}$ & $\begin{array}{l}53 \\
43-67\end{array}$ & $\begin{array}{l}18 \\
12-22\end{array}$ & $\begin{array}{l}26 \\
15-50\end{array}$ & $\begin{array}{c}3 \\
0.3-4\end{array}$ & $\begin{array}{l}7 \\
2-14\end{array}$ & $\begin{array}{l}16 \\
11-26\end{array}$ & $\begin{array}{l}1 \\
0-2\end{array}$ \\
\hline & 40 & $\begin{array}{l}2 \\
1-3\end{array}$ & $\begin{array}{l}1 \\
1-1\end{array}$ & $\begin{array}{l}45 \\
36-62\end{array}$ & $\begin{array}{l}23 \\
19-29\end{array}$ & $\begin{array}{l}29 \\
13-44\end{array}$ & $\begin{array}{l}2 \\
1-5\end{array}$ & ${ }_{2-15}^{9}$ & $\stackrel{18}{9-23}$ & $\stackrel{1}{0.7-14}$ \\
\hline 33 & 43 & $\begin{array}{l}2 \\
1-3\end{array}$ & $\begin{array}{l}1 \\
1-1\end{array}$ & $\begin{array}{l}37 \\
29-50\end{array}$ & $\begin{array}{l}47 \\
35-57\end{array}$ & $\stackrel{13}{4-18}$ & $\begin{array}{l}1 \\
1-1\end{array}$ & $\begin{array}{l}1 \\
1-2\end{array}$ & $\begin{array}{l}11 \\
8-15\end{array}$ & 0 \\
\hline 7 & 50 & $\begin{array}{l}3 \\
1-4\end{array}$ & $\begin{array}{l}3 \\
0-6\end{array}$ & $\begin{array}{l}55 \\
52-60\end{array}$ & $\begin{array}{l}35 \\
30-43\end{array}$ & $\begin{array}{l}4 \\
0-17\end{array}$ & 0 & $\begin{array}{l}1 \\
0-3\end{array}$ & $\begin{array}{l}3 \\
0-13\end{array}$ & 0 \\
\hline 4 & 60 & $\begin{array}{l}2 \\
1-2\end{array}$ & $\begin{array}{l}1 \\
0-0.6\end{array}$ & $\begin{array}{l}58 \\
55-80\end{array}$ & $\begin{array}{l}35 \\
14-40\end{array}$ & $\begin{array}{l}4 \\
1-7\end{array}$ & 0 & $\begin{array}{l}1 \\
0-7\end{array}$ & $\begin{array}{l}3 \\
1-6\end{array}$ & 0 \\
\hline
\end{tabular}

* Animals were nephrectomized 48 hours before sacrifice. For explanation of symbols, see Table II.

ing maternal polycythemia on neonatal erythropoiesis is given in Table IV. The anticipated decrease in maternal erythropoiesis is evident from the reticulocytopenia, erythroid differential, and absence of erythroid mitoses. The newborn controls had both peripheral blood and bone marrow values similar to those seen in newborns nursing from normal mothers. Litter mates were nephrectomized and sacrificed after 49 or 72 hours. The bone marrow differentials and reticulocytes were comparable to the controls; the hematocrits and mitotic indexes were slightly lower than the litter mate controls but within the range seen in other normals of similar age.

\section{Discussion}

The early neonatal period of the rat is characterized by a macrocytic hypochromic anemia. The rate of disappearance of macrocytes, the degree of erythroid hyperplasia, and reticulocytosis lead to the conclusion that it is a partially compensated hemolytic anemia. The anemia is unusual in that there is both marked hypochromia

TABLE IV

Effect of maternal transfusion on neonatal erythropoiesis*

\begin{tabular}{|c|c|c|c|c|c|c|c|c|c|}
\hline Treatment & Age & Weight & $\begin{array}{c}\text { Hemato- } \\
\text { ctit }\end{array}$ & $\begin{array}{l}\text { Reticulo- } \\
\text { cytes }\end{array}$ & Erythroid & Prn & $\mathrm{BN}$ & PN & MI \\
\hline & days & $g$ & $\%$ & $\%$ & $\%$ & $\%$ & $\%$ & $\%$ & $\%$ \\
\hline Mother & & & 65 & 0.1 & 0.4 & 0 & 0 & 0.4 & 0 \\
\hline Control (1)t & 3 & 9 & 32 & 41 & 57 & 9 & 20 & 28 & 6.4 \\
\hline Control (3) & 4 & 10 & 31 & 45 & 58 & 9 & 24 & 25 & 5.2 \\
\hline Nephrectomy (3) & 3 & 6 & 30 & 38 & 64 & 9 & 25 & 30 & 3.7 \\
\hline Nephrectomy (2) $\ddagger$ & 4 & 8 & 27 & 43 & 57 & 8 & 20 & 29 & 2.8 \\
\hline
\end{tabular}

* Nephrectomy was done on the first day of life and animals sacrificed at 49 or 72 hours thereafter; litter mates served as controls. The mother was transfused 2,3 , and 5 days before delivery and sacrificed on the fourth day after delivery. See Table II for symbols.

$\dagger$ Number in parentheses $=$ number of animals.

$\$$ Hematocrits, reticulocytes, and mitotic index based on a single animal; the second animal was found dead at $\sim 72$ hours; the bone marrow preparation was adequate for evaluating the differential. 
and macrocytosis. It is evident that the hypochromia cannot be attributed solely to early release of cells in a stimulated marrow, analogous, e.g., to the mild early hypochromia in animals responding to severe phenylhydrazine-induced anemia. If this were the case, there should be a direct relationship between the degree of reticulocytosis and hypochromia; this was not observed (Table I). Moreover, if early release were the explanation, the mature (nonreticulated) cells would be normochromic (hemoglobin concentration, 33). To achieve the observed MCHC of 27.7 on day 10 with $29 \%$ reticulocytes would require a mean reticulocyte hemoglobin concentration of $\sim 15 \%$. A normal distribution of hemoglobin concentration about this mean implies negative values (i.e., less than 0 ); asymmetrical distribution would imply acceleration of hemoglobin synthesis as the reticulocyte ages and loses its RNA; in either event most, if not all, of the hemoglobin would be formed after reaching the reticulocyte stage. Clearly, these possibilities are untenable, and one must assume that a true hypochromic anemia exists. Jacobson and associates (15) observed that neither anemia nor hypochromia developed when Imferon was given throughout pregnancy, suggesting that hypochromia is due to iron deficiency. If this be the case, then the response of the newborn rat to iron deficiency differs from that seen in adult rats or in human beings where microcytosis rather than macrocytosis invariably develops before hypochromia in the iron-deficient subject $(18,19)$. This points to a different regulatory mechanism for erythropoiesis in the newborn rat.

The failure of nephrectomy to alter the rate of erythropoiesis during the neonatal period provides clear evidence that erythropoiesis in the newborn rat is independent of renally produced erythropoietin. The possibility of maternal transfer of erythropoietin through the milk was excluded by studies in which nephrectomized newborns nursed from hypertransfused mothers. Although there is some evidence to suggest extrarenal sites of erythropoietin production in adults, the extent of erythropoietin production by these sources (14) appears inadequate to support erythropoiesis of the magnitude observed in the newborn period. Here the animal must compensate not only for a period of rapid growth but also for a severe hemolytic process.

The difference in the type of response, i.e., hypochromic macrocytosis in the presence of presumed iron deficiency, and the lack of dependence of erythropoiesis on the kidney, then, clearly indicate regulatory mechanisms other than renally dependent erythropoietin. Is this mechanism sensitive to hypoxia? Although it is not possible to provide a conclusive answer with the data at hand, the erythroid response to a relatively mild degree of anemia would suggest that hypoxia does not play the dominant role. A similar argument has been used to explain the relatively high red cell production in compensated hemolytic syndromes in $\operatorname{man}(2,4,5)$.

The mechanism of macrocytosis in the newborn animals, likewise, remains unexplained. In adults it has been postulated and evidence adduced $(18,20)$ to support the notion that when a critical cytoplasmic hemoglobin concentration ( $\mathrm{CHC}$ ) is reached, a negative feedback is triggered that shuts off nucleic acid synthesis and division. When the rate of hemoglobin synthesis is accelerated, the time required to achieve the critical $\mathrm{CHC}$ is shortened. This in the face of a fixed interphase results in skipped terminal divisions and macrocytosis. A decrease in the rate of hemoglobin synthesis permits additional divisions and microcytosis results. This predicts, of course, microcytosis in the presence of hypochromia, which is the case in adults $(19,21)$. Perhaps in the newborn the critical hemoglobin concentration for shutoff of division differs from adults. This is open to experimental verification. It should be noted, however, that the above mechanism is predicated on a fixed interphase time that has been demonstrated for adult erythropoiesis (22. 23). This may not be the case in the newborn. The difference in mitotic index of 3 to $5 \%$ in the newborn as contrasted with $\sim 1 \%$ in the adult indicates a difference in the generation time for erythroid cells in the newborn and further raises the possibility of a variable interphase. It appears, then, that not only the mechanism of regulation but the kinetics of proliferation of red cells in the newborn rat may differ from the adult.

In the newborn rat erythropoiesis is normoblastic and appears to develop from a primitive syn- 
cytial type of stem cell similar to that described in fetal hematopoietic tissues of the human (24). At about the fifteenth day, the numbers of these cells decrease and are no longer present after the fortieth day; instead there are individual cells, which one might classify as reticulum cells. Whether these serve as stem cells in adult life is moot. The change in responsiveness to nephrectomy occurs as these syncytial cells disappear. This in turn raises the question of whether the primitive mesenchymal cell acts as an "ultimate" stem cell with a more "differentiated" stem cell (perhaps a reticulum cell) serving as the immediate precursor, which in adult life is responsive to erythropoietin.

The changes in erythropoiesis in the newborn rat are not analogous to those seen in newborn human beings. In man the newborn period is associated with a relative marrow hypoplasia as the hemoglobin decreases from polycythemic values seen at birth to the normal values seen by 3 months. The relative marrow hypoplasia does not reflect relative polycythemia alone. In erythroblastotic infants, who are not exchange transfused, the marrow does not respond to the anticipated degree in the face of severe anemia of 6 to $8 \mathrm{~g}$ (25). This may reflect a time lag in the changeover from fetal to adult erythropoiesis. Macrocytosis, although present, is minimal compared to that in the rat. The degree of macrocytosis, however, is a function of maturity in man; the more premature a baby the greater is the degree of macrocytosis (26). Since the rat is much more immature at birth than man, it might be suggested that neonatal erythropoiesis in the rat is analogous to fetal rather than neonatal erythropoiesis in man. In support of such a view is the fact that in the human embryo at about 5 months the liver has primarily erythropoiesis and the marrow has leukopoiesis; later the marrow begins to support hematopoiesis entirely (25). Not only does an analogous situation obtain during the first week of life in the rat, but the morphology of the "stem cell" and the degree of macrocytosis at this stage of human fetal development are similar to those seen in the newborn rat (24). If so, then a "fetal" type of cell production might be anticipated in the rat even after birth with the production of fetal rather than adult type hemoglobin. Thus, different structural loci for hemoglobin synthesis and regulation of nucleic acid synthesis and division might be anticipated. This could provide a tentative explanation for the difference in red cell production between adult and newborn.

\section{Summary}

Normal newborn rats have a hemolytic anemia characterized by hypochromic macrocytosis. The hemolysis, although substantial, is largely compensated for by intense erythropoiesis so that the anemia itself is relatively mild. The character of the erythropoietic response, i.e., production of hypochromic macrocytic cells, and the high mitotic index suggest that red cell production is governed by a different mechanism than in adults. Further support for this thesis was provided by studies on nephrectomized newborns. Nephrectomy did not importantly affect erythropoiesis during the first 20 days of life. Transfer of maternal erythropoietin through the milk was excluded by suppressing maternal erythropoietin production by hypertransfusion.

We conclude that red cell production in the newborn rat operates independently of renally produced erythropoietin. It is further suggested that red cell production in the newborn rat is analogous to fetal erythropoiesis in human beings.

\section{References}

1. Fried, W., L. F. Plzak, L. O. Jacobson, and E. Goldwasser. Studies on erythropoiesis III. Factors controlling erythropoietin production. Proc. Soc. exp. Biol. (N. Y.) 1957, 94, 237.

2. Stohlman, F., Jr. Observations on the physiology of erythropoietin and its role in the regulation of red cell production. Ann. N. Y. Acad. Sci. 1959, 77, 710.

3. Fliedner, T. M., F. Stohlman, Jr., and E. P. Cronkite. Unpublished data.

4. Brown, J. R., N. Altschuler, and J. A. D. Cooper. Erythropoietic effect of red cell components and heme-related compounds. Proc. Soc. exp. Biol. (N. Y.) 1963, 112, 840.

5. Sánchez-Medal, L., J. Labardini, and A. Loría. Hemolysis and erythropoiesis. Blood 1963, 21, 586.

6. Jacobson, L. O., E. Goldwasser, W. Fried, and L. Plzak. Role of the kidney in erythropoiesis. Nature (Lond.) 1957, 179, 633. 
7. Naets, J.-P. The role of kidney in erythropoiesis. J. clin. Invest. 1960, 39, 102.

8. Nathan, D. G., E. Schupak, F. Stohlman, Jr., and J. P. Merrill. Erythropoiesis in anephric man.' J. clin. Invest. 1964, 43, 2158.

9. Jacobson, L. O., E. Goldwasser, and C. W. Gurney. Control of red cell formation in Kinetics of Cellular Proliferation, F. Stohlman, Jr., Ed. New York, Grune \& Stratton, 1959, pp. 344-356.

10. Mirand, E. A., T. C. Prentice, and W. R. Slaunwhite. Current studies on the role of erythropoietin on erythropoiesis. Ann. N. Y. Acad. Sci. 1959, 77, 677.

11. Kuratowska, Z., B. Lewartowski, and E. Michalak. Studies on the production of erythropoietin by isolated perfused organs. Blood 1961, 18, 527.

12. Reissmann, K. R., and T. Nomura. Erythropoietin formation in isolated kidney and liver in Erythropoiesis, L. O. Jacobson and M. A. Doyle, Eds. New York, Grune \& Stratton, 1962, p. 71.

13. Fisher, J. W., N. P. Sanzari, B. J. Birdwell, and J. J. Crook. Role of kidney in erythropoietin production in Erythropoiesis, L. O. Jacobson and M. A. Doyle, Eds. New York, Grune \& Stratton, 1962, p. 78.

14. Rosse, W. F., and T. A. Waldmann. The role of the kidney in the erythropoietic response to hypoxia in parabiotic rats. Blood 1962, 19, 75.

15. Jacobson, L. O., E. K. Marks, and E. O. Gaston. Studies on erythropoiesis XII. The effect of transfusion-induced polycythemia in the mother on the fetus. Blood 1959, 14, 644.

16. Brecher, G., and F. Stohlman, Jr. Reticulocyte size and erythropoietic stimulation. Proc. Soc. exp. Biol. (N. Y.) 1961, 107, 887.
17. Grant, W. C. The influence of anoxia of lactating rats and mice on blood of their normal offspring. Blood 1955, 10, 334.

18. Stohlman, F., Jr., D. Howard, and A. Beland. Humoral regulation of erythropoiesis XII. Effect of erythropoietin and iron on cell size in iron deficiency anemia. Proc. Soc. exp. Biol. (N. Y.) 1963, 113, 986.

19. Moores, R. R., F. Stohlman, Jr., and G. Brecher. Humoral regulation of erythropoiesis XI. The pattern of response to specific therapy in iron deficiency anemia. Blood 1963, 22, 286.

20. Stohlman, F., Jr., A. Beland, and D. Howard. Mechanism of macrocytic response to erythropoietin (abstract). J. clin. Invest. 1963, 42, 984.

21. Conrad, M. E., and W. H. Crosby. The natural history of iron deficiency induced by phlebotomy. Blood 1962, 20, 173.

22. Alpen, E. L., and D. Cranmore. Observations on regulation of erythropoiesis and on cellular dynamics by $\mathrm{Fe}-59$ autoradiography in The Kinetics of Cellular Proliferation, F. Stohlman, Jr., Ed. New York, Grune \& Stratton, 1959, pp. 290-300.

23. Bond, V. P., N. Odartchenko, L. Feinendegen, N. Cottier, and E. P. Cronkite. Kinetics of more mature erythrocytic precursors studied with tritiated thymidine in Erythropoiesis, L. O. Jacobson and M. A. Doyle, Eds. New York, Grune \& Stratton, 1962, p. 173.

24. Maximow, A. A. Relation of blood cells to connective tissues and endothelium. Physiol. Rev. 1924, 4, 533.

25. Leventhal, B., and F. Stohlman, Jr. Unpublished observations.

26. Wintrobe, M. M. Clinical Hematology. Philadelphia, Lea \& Febiger, 1961, pp. 31-40. 